\title{
FORMASI KEBUTUHAN PEGAWAI DALAM PENERIMAAN CALON PEGAWAI NEGERI SIPIL (CPNS) BADAN KEPEGAWAIAN DAERAH KOTA MAKASSAR
}

\author{
AULIYA CITRA R ${ }^{(1)}$, MUH.YUNUS ${ }^{(2)}$ \\ Ilmu Administrasi Publik Universitas Muhammadiyah \\ auliyacitra@gmail.com.1Yunusmuh34@gmail.com.²
}

\begin{abstract}
The aim of this research was to clescribe how the formation needs of servant in acceptance prospective civil servant like BKD Kota Makassar. This research was about a descriptive qualitative research. The data sourched by primer and sekunder data. The data was collected through observation and statement analysis. The observation was used to analysis qualitative data through technique analysis and statement analysis was taken from the result of interviewing informan and endorsement data intensively. The finding of this research showed that the servant need was not enough. It based on from position and job's formation where the appropriate competence. Level toward apparatus position is not agree with conditions.
\end{abstract}

Keywords: formation, supplies, officer in acceptance CPNS

\begin{abstract}
Abstrak
Tujuan penelitian ini adalah untuk mengkaji bagaiman formasi kebutuhan pegawai dalam penerimaan calon pegawai negeri sipil, yaitu Badan Kepegawaian Daerah Kota Makassar. Jenis penelitian ini adalah deskriptif kualitatif, data bersumber dari data primer dan data sekunder. pengumpulan data observasi dengan teknik analisis data kualitatif secara analisis melalui konteks pustaka dan analisis pernyataan dari hasil wawancara mendalam dari informan dan pengabsahan data. Dari hasil penelitian yang dilakukan menunjukan bahwa kebutuhan pegawai belum terpenuhi. Hal ini berdasarkan dari formasi jabatan dan formasi beban kerja, dimana tingkat kesesuaian kompetensi terhadap jabatan aparatur belum sesuai dengan syarat-syarat.
\end{abstract}

Kata kunci : formasi, kebutuhan, Pegawai dalam peneriman CPNS 


\section{PENDAHULUAN}

Sumber daya manusia merupakan salah satu faktor yang sangat penting dalam proses pencapaian tujuan organisasi. Sumber daya manusia memiliki peran dan fungsi yang sangat vital dan tidak dapat digantikan oleh sumber daya lainnya, Karena sumber daya manusia merupakan satu-satunya sumber daya yang dapat membuat sumber daya lainnya berjalan. Kemajuan dan keberhasilan suatu organisasi sangat ditentukan oleh kualitas dan kapabilitas sumber daya manusia di dalamnya.Karena pentingnya peranan sumber daya manusia dalam suatu organisasi maka sudah sepatutnya suatu organisasi memiliki sumber daya manusia yang berkompeten dalam bidangnya. Kualitas dan kuantitas sumber daya manusia dalam suatu organisasi hendaknya disesuaikan dengan kebutuhan organisasi yang bersangkutan supaya efektif dan efisien dalam menunjang tercapainya tujuan.

Salah satu cara dalam mencari sumber daya manusia yang berkualitas yaitu melalui rekrutmen. Rekrutmen tenaga kerja dibutuhkan untuk menyaring para pelamar yang ingin melamar guna mengatasi kekurangan kebutuhan sumber daya manusia. Rekrutmen merupakan proses mencari, menemukan, dan menarik pelamar untuk dipekerjakan dalam suatu organisasi. Melalui rekrutmen individu yang memiliki keahlian yang dibutuhkan didorong membuat lamaran untuk lowongan kerja yang tersedia di organisasi.melalui rekrutmen pula organisasi dapat melakukan komunikasi dengan pihak-pihak tertentu untuk memperoleh sumber daya manusia yang potensial. Semakin banyak calon yang berhasil dikumpulkan maka akan semakin baik karena kemungkinan untuk mendapatkan calon terbaik akan semakin besar.

Sumber daya manusia kini makin berperan besar bagi kesuksesan suatu organisasi. Banyak organisasi menyadari bahwa unsur manusia dalam suatu organisasi dapat memberikan keunggulan bersaing. Mereka membuat sasaran, strategi, inovasi, dan mencapai tujuan organisasi. Oleh karena itu, sumber daya manusia merupakan salah sat unsur yang paling vital bagi organisasi. Terdapat dua alasan dalam hal ini. Pertama, sumber daya manusia memengaruhi efisiensi 
dan efektivitas organisasi-sumber daya manusia merancang dan memproduksi barang dan jasa, mengawasi kualitas, memasarkan produk, mengalokasikan sumber daya finansial, serta menentukan seluruh tujuan dan strategi organisasi.Kedua, sumber daya manusia merupakan pengeluaran utama organisasi dalam menjalankan bisnis.

Pengadaan pegawai negeri sipil merupakan proses kegiatan untuk mengisi formasi yang lowong dimulai dari perencanaan, pengumuman, pelamaran, penyaringan, penetapan kelulusan, permintaan Nomor Identitas Pegawai Negeri Sipil (NIP) sampai dengan pengangkatan menjadi CPNS. Lowongan formasi pada suatu organisasi pemerintahan pada umumnya disebabkan adanya PNS yang berhenti karena pensiun, meninggal dunia, mutasi jabatan, pengembangan organisasi atau karena sebab lainnya. Karena pengadaan pegawai negeri sipil dimaksudkan untuk mengisi formasi yang lowong, oleh karena itu maka pengadaan pegawai tersebut dilaksanakan atas dasar kebutuhan penambahan pegawai, baik dalam arti jumlah, kualitas pegawai serta kompetensi jabatan yang dibutuhkan. Untuk itu, setiap warga negara republik Indonesia yang memenuhi syarat yang ditentukan dalam peraturan perundang-undangan yang berlaku diberikesempatan yang sama untuk mengajukan lamaran pekerjaan sebagai calon pegawai negeri sipil.

Salah satu bagian yang penting dalam manajemen sumber daya manusia adalah merencanakan tenaga kerja agar sesuai dengan kebutuhan perusahaan serta efektif dan efisien dalam membantu terwujudnya tujuan. ${ }^{1}$ Mengemukakan perencanaan sumber daya manusia adalah suatu perencanaan yang sistematik tentang perkiraan kebutuhan dan pengadaan tentang pegawai dalam penempatan CPNS dan tidak sesuai kebutuhan yang ada di BKD banya pengawai salah formasi untuk mendaftar PNS. $^{2}$ Alex S. Nitisemito berpendapat bahwa: manajemen personalia adalah suatu ilmu seni untuk melaksanakan antara lain

\footnotetext{
13.

${ }^{1}$ Malayu Hasibuan, Manajemen Sumber Daya Manusia (Jakarta: Bumi Aksara, 2011), h.

${ }^{2}$ Edy Sutrisno, Manajemen Sumber Daya Manusia (Jakarta: Kencana Prenada Media Group, 2009), h. 20.
} 
planning, organizing, controlling, sehingga efektivitas dan efisiensi personalia dapat ditingkatkan semaksimal mungkin dalam pencapaian tujuan. ${ }^{3}$

Gary Dessler dalam Akhmad Subekhi mengemukakan analisis jabatan (job analysis) adalah prosedur untuk menetapkan tugas dan tuntutan keterampilan dari suatu jabatan dan orang macam apa yang akan dipekerjakan untuk itu. ${ }^{4}$ Formasi jabatan adalah teknik menghimpun, mengolah dan menyajikan informasi pekerjaan-pekerjaan secara sistematis, tepat dan jelas untuk keperluan penyusunan kegiatan-kegiatan dalam pengelolaan tenaga kerja. ${ }^{5}$

Dalam bukunya yang berjudul Dasar-Dasar Manajemen, M. Manullang mendefinisikan bahwa: manajemen kepegawaian (personnel management) adalah seni dan ilmu perencanaan, pelaksanaan dan pengontrolan tenaga kerja untuk tercapainya tujuan yang telah ditentukan terlebih dahulu dengan adanya kepuasan hati pada diri para pegawai. ${ }^{6}$

Penentuan kebutuhan tenaga kerja menyangkut jumlah maupun mutu tenaga kerja. Sebelum pelaksanaan fungsi pengadaan tenaga kerja, perlu terlebih dahulu ditentukan:1) Kualitas atau mutu tenaga kerja yang diinginkan sesuai dengan jenis pekerjaan atau jabatan serta persyaratan jabatan yang ada; 2) Jumlah dan jenis tenaga kerja yang dibutuhkan berdasarkan tingkat pendidikan atau keahliannya. ${ }^{7}$

Peraturan Perundang-undangan yang mengatur tentang Aparatur Negara yang di dalamnya terdapat PNS dipandang perlu adanya penyesuaian terhadap perkembangan zaman. PNS adalah Aparatur Negara, Abdi Negara dan Abdi Masyarakat yang diangkat dan dipekerjakan berdasarkan Undang-Undang Nomor 8 Tahun 1974 disempurnakan dengan Undang-Undang Nomor 43 Tahun 1999 dan

${ }^{3}$ Alex Nitisemito, Manajemen Personalia: Manajemen Sumber Daya Manusia (Jakarta: Ghalia Indoneisa, 1982), h.10.

${ }^{4}$ Akhmad Subekhi, Pengantar Manajemen Sumber Daya Manusia (MSDM).(Jakarta: Prestasi Pustaka, 2012), h. 98.

${ }^{5}$ Batinggi, dkk, Modul Manajemen Sumber Daya Manusia (Ujung Pandang: STIMIK Dipanegara, 1998), h. 21.

${ }^{6}$ M. Manullang, Dasar-Dasar Manajemen (Yogyakarta: Gadjah Mada University Press), h.24.

${ }^{7}$ Sadili Samsudin, Manajemen Sumber Daya Manusia (Bandung: CV. Pustaka Setia, 2006), h. 62 . 
diberikan hak pensiun atau jaminan hari tua beserta pensiun janda/duda/untuk anak PNS, berdasarkan Undang-Undang Nomor 11 Tahun 1969. Menindaklanjuti Undang-Undang Nomor 5 Tahun 2014 tentang Aparatur Sipil Negara (ASN) Kepala Badan Kepegawaian Negara mengeluarkan surat Nomor K.26-30/V.73/99 tanggal 17 Januari 2014 perihal Batas Usia Pensiun Pegawai Negeri Sipil 55 Tahun.

Melakukan proyeksi kebutuhan pegawai. Khusus di lingkup Pemerintah Kota Makassar, Untuk penerimaan CPNS 2014 Berdasarkan data dari Badan Kepegawaian Daerah Kota Makassar sebanyak kurang lebih 7000 orang CPNS. Kemudian diseleksi kembali menjadi 2000 orang CPNS.Dari 2000 orang CPNS hanya 88 orang yang diterima menjadi Pegawai Negeri Sipil.

\section{METODE PENELITIAN}

Penelitian yang diawali dengan peninjauan ke lokasi penelitian hingga penulisan skripsi kurang lebih dalam dua bulan mulai tanggal 22 Juli sampai dengan 21 September 2014. Penelitian ini dilaksanakan di kantor dinas Badan Kepegawaian Derah Kota Makassar karena dinilai dari seberapa besar penanganan secara keseluruhan mengenai Formasi Kebutuhan Pegawai Dalam penerimaan Calon Pegawai Negeri Sipil. Jenis penelitiannya adalah wawancara kepada narasumber/informan yang berisi pertanyaan-pertanyaan mengenai hal yang berhubungan dengan rumusan masalah penelitian dan tipe penelitian yang digunakan oleh penulis dalam penelitian ini adalah deskriptif kualitatif. Informan merupakan orang-orang yang berpotensi memberikan informasi tentang permasalahan Formasi Kebutuhan Pengawai Dalam Penerimaan CPNS Pada Badan Kepegawaian Daerah Kota Makassar, informasi terdidri dari 5 orang yaitu:(1) Sekretaris Badan Kepegawaian Daerah Kota Makassar; (2) Kasubbag Umum dan Kepegawaian Badan Kepegawaian Daerah Kota Makassar; (3)Kasubbid Perencanaan Pegawai Badan Kepegawaian Daerah Kota Makassar; (4)Kasubbid Peningkatan Kompetensi Badan Kepegawaian Daerah Kota Makassar; (5)Kasubbid Data \& Informasi Badan Kepegawaian Daerah Kota Makassar. 


\section{HASIL PENELITIAN DAN PEMBAHASAN}

Uraian pekerjaan atau jabatan harus ditetapkan secara jelas untuk setiap jabatan, supaya pejabat tersebut mengetahui tugas dan tanggung jawab yang harus dilakukan. Uraian pekerjaan akan memberikan ketegasan dan standar tugas yang harus dicapai oleh seorang pejabat yang memegang jabatan tersebut. Uraian pekerjaan ini menjadi dasar untuk menetapkan spesifikasi pekerjaan bagi pejabat yang memegang jabatan itu. Uraian pekerjaan yang kurang jelas akan mengakibatkan seorang pejabat kurang mengetahui tugas dan tanggung jawabnya. Hal ini mengakibatkan pekerjaan tidak beres.Disinilah letak pentingnya peranan uraian pekerjaan dalam setiap organisasi.

Ringkasan jabatan/uraian pekerjaan setiap unit pada Badan Kepegawaian Daerah Kota Makassar, bahwa ringkasan jabatan/uraian pekerjaan belum jelas dan belum mampu dipahami oleh setiap pegawai dan belum jelas dan belum terperinci, karena pegawai pada setiap bidang belum memahami dengan baik tugas-tugas yang diberikan,para pegawai dinggap belum mampu untuk memahami tugas yang telah di berikan oleh Pegawai belum memahaminya tugas pokok dan fungsinya masing-masing. Jadi mampu menarik sebuah kesimpulan bahwa kondisi pegawai di Badan Kepegawaian Daerah kota makassar hingga saat ini belum mampu untuk memahami ringkasan jabatan/uraian pekerjaan mereka masing-masing.

Tugas dan tanggung jawab secara nyata diuraikan secara terpisah agar jelas.Karna hubungan kerja setiap bidang pada Badan Kepegawaian Daerah Kota Makassar saling terkait, misalnya ada kenaikan pangkat atau ada pegawai yang dipromosi maka harus ada komunikasi antara bidang pendayahgunaan, bidang data dan informasi.Setiap jabatan dalam Badan Kepegawaian Daerah Kota Makassar saling berhubungan satu sama lain, setiap bidang memiliki hubungan kerja terutama dalam pelaksanaan tugas-tugas organisasi. Pegawai di Badan Kepegawaian Daerah ini saling membantu antar bidang yang membutuhkan, tetapi ada yang dinamakan skala prioritas, pekerjaan yang mendesak lebih didahulukan, dalammengenalisis fungsi dan tanggung jawab, dalam hal ini hubungan kerja dan jabatan sudah terealisasi dengan baik antar setiap bagian yang 
ada.Setiap bidang saling berkaitan terutama dalam pelaksanaan tugas dan pencapaian tujuan dan sasaran, Kalau misalnya seperti kenaikan gaji berkala itu diberikan kepada pegawai setiap 2 tahun kan itu dengan catatan bahwa rajin apel dan catatan-catatan lainnya artinya komunikasi antara bidang kinerja dan mutasi. Jadi dapat menyimpulkan bahwa dalam mengenali fungsi dan tanggung jawab, dalam hal ini hubungan kerja dan jabatan sudah terealisasi dengan baik antar setiap bagian yang ada dalam badan kepegawaian daerah kota makassar.

Seperti yang dijelaskan sebelumnya, tugas dan pekerjaan telah diuraikan pada setiap jabatan dan tugas itulah yang harus dilaksanakan oleh pegawai yang bersangkutan dalam hal ini pemegang jabatan. Berkenaan dengan seperti apa tindakan pegawai ketika terdapat pekerjaan pada bagian lain yang harus pula dilakukan. Pegawai di Badan Kepegawaian Daerah ini saling membantu antar bidang yang membutuhkan, Pendapat ini di sempurnakan tetapi ada yang dinamakan skala prioritas, pekerjaan yang mendesak lebih didahulukan.

Persyaratan pekerjaan/jabatan diperoleh dari uraian jabatan yang menitikberatkan pada syarat-syarat mengenai orang yang diperlukan untuk memegang suatu jabatan dan untuk mencapai hasil kerja yang lebih baik.Persyaratan jabatan banyak digunakan sebagai dasar untuk pencarian calon pegawai, penempatan, pemindahan dan kenaikan jabatan.Banyak hal yang perlu diperhatikan untuk menempatkan pegawai dalam suatu jabatan.

Memperhatikan tingkat pendidikan seseorang sudah menjadi hal yang sangat penting dalam penempatan pegawai agar pegawai bekerja sesuai dengan kompetensinya. Berkenan dengan seperti apa formasi pegawai pada Badan Kepegawaian Daerah Kota Makassar, Penempatan pegawai saat ini sebagian besar sudah sesuai dengan latar pendidikan, walaupun masih ada beberapa yang tidak sesuai dengan latar pendidikannya. Namun begitu juga karena pengalaman, dia akhirnya tahu malahan akhirnya lebih bisa dibanding orang yang memiliki latar pendidikan.karena bukan organisasi baru, tentunya ada pegawai yang latar pendidikannya sudah sesuai dan ada yang tidak.

Akan tetapi mereka memiliki pengalaman dan kemampuan soal jabatan yang diberikan. Di dalam anjab memang telah diatur tentang syarat jabatan 
termasuk latar pendidikan yang dibutuhkan untuk suatu jabatan jadi sebisa mungkin hal tersebut harus terpenuhi atau paling tidak mendekati disiplin ilmu tersebut, tetapi hal tersebut tidaklah mutlak harus terpenuhi karena pendidikan formal bukanlah indikator satu-satunya dalam penempatan seorang pejabat.Jadi dapat menyimpulkan bahwa jika dilihat dari latar belakang pendidikan, formasi pegawai pada Badan Kepegawaian Daerah Kota Makassar belum seratus persen sesuai dengan latar belakang pendidikan, masih ada pegawai yang menempati suatu jabatan yang tidak sesuai dengan latar pendidikan yang dimiliki. Akan tetapi mereka memiliki pengalaman dan kemampuan soal jabatan yang diberikan.Jadi dapat di katakan bahwa idealnya suatu jabatan harus sesuai dengan jabatan yang di laju, latar belakang pendidikan, serta pengalaman yang dimiliki oleh seorang pegawai sehingga dapt menyusun program dan mencapai target dari visi misi yang ada.

Kompetensi menjelaskan apa yang dilakukan orang ditempat kerja pada berbagai tingkatankemampuan/kompetensi pegawai, Kalau bicara jabatan, ada jabatan struktural ada memang yang istilahnya jabatan yang staf, staf umum dan Jabatan fungsional, tapi kalau untuk Badan Kepegawaian Daerah jabatan fungsional itu kita tidak ada. Terus kalau jabatan struktural sepanjang ini yg ditempatkan di Badan Kepegawaian Daerah oleh BAPERJAKAT, BAPERJAKAT serta anggotanya Sekda dan Kepala Badan Kepegawaian Daerah, saya anggap penempatan pejabat di Badan Kepegawaian Daerahbelum sesuai dengan kompetensinya masing-masing. Kemampuan seorang pegawai dapat dilihat saat melaksanakan tugas dan tanggung jawab yang diberikan, melihat kesulitan atau kendala-kendala yang dihadapi oleh pegawai saat menyelesaikan pekerjaan.Dari kemampuan pegawai terutama dalam melaksanakan tupoksi pegawai jarang mengalami kesulitan, juga tidak ada kendala-kendala yang begitu berarti.Secara ideal peningkatan jabatan yang menjadi pertimbangan adalah pangkat sesuai dengan jabatan yang di laju, latar belakang pendidikan sesuai dengan jurusan kemudian pengalaman CPNS.Pada dasarnya semua PNS paham atas tupoksinya namun masih terdapat atau masih sering di temukan beberapa PNS yang kurang memahami tupoksinya hal tersebut bukan karna PNS berlatar 
belakang pendidikan rendah melainkan sudah menjadi karakter atau sudah menjadi budaya di dalam organisasi pemerintah. Jadi dapat di katakan bahwa penempatan jabatan struktural pada Badan Kepegawaian Kota Makassar di terapkan berdasarkan pengalam serta pendidikan yang dimiliki oeh sorang pegawai dan pengalamn dari sorang pegawai yang memahami bidang kerja mereka, sehingga bisa berjalan secara efektif dan efisien.

Beban kerja adalah suatu teknik manajemen yang dilakukan secara sistematis untuk memperoleh informasi mengenai tingkat efisiensi dan efektivitas kerja organisasi berdasarkan volume kerja. Beban kerja tersebut diperoleh dari hasil kali antara volume kerja dan norma waktu. Volume kerja adalah sekumpulan tugas atau pekerjaan yang harus/dapat diselesaikan dalam waktu satu tahun. Norma waktu adalah waktuyang wajar dan nyata-nyata dipergunakan secara efektif dengan kondisi normal oleh seorang pemangku jabatan untuk menyelesaikan suatu tahapan proses penyelesaian pekerjaan.Sesuai dengan PP 100 Tahun 2000 yang telah diubah menjadi PP 23 Tahun 2002 telah ada aturan tentang penempatan pegawai dalam jabatan struktural. Salah satunya adalah anjab yang bisa dijadikan landasan.Jadi sebisa mungkin pegawai ditempatkan sesuai dengan kompetensi yang dimilikinya.Walaupun hal tersebut belum bisa terpenuhi sepenuhnya karena setiap individu memiliki keterbatasan. Tetapi secara keseluruhan, pola penempatan pegawai sudah bisa dianggap sesuai dengan kompetensi yang dimiliki Jadi dapat di katakan bahwa beban kerja dan Jumlah Pegawai pada Badan Kepegawaian Daerah Kota Makassar sudah cukup seimbang, dan untuk sementara tidak perlu ada penambahan pegawai.

Beban kerja merupakan faktor penting dalam menghitung kebutuhan pegawai. Beban kerja ditetapkan berdasarkan tugas dan fungsi unit organisasi yang selanjutnya diuraikan menjadi rincian tugas yang diselesaikan pada jangka waktu tertentu. Indikator yang mendasari seseorang ditempatkan pada suatu jabatan sebenarnya telah diatur di dalam formasi jabatan, dimana dalam formasi jabatan ada uraian jabatan dan syarat-syarat jabatan. Uraian jabatan ini merupakan rincian dari beban kerja yang kemudian dijadikan sebagai landasan untuk menentukan jabatan, jenis orang dan kompetensi seperti apa yang dibutuhkan. 
Jadi disini bukan beban kerja yang kemudian menyesuaikan diri dengan kemampuan/kompetensi pegawai, tapi sebaliknya.Sejauh ini, kondisi beban kerja yang ada, sudah sesuai dengan kompetensi pegawai.menyimpulkan bahwa uraian jabatan merupakan rincian dari beban kerja yang kemudian kompetensi yang dimilikinya. Walaupun hal tersebut belum bisa terpenuhi sepenuhnya, beban kerja yang ada sudah dianggap sesuai dengan kompetensi yang dimiliki oleh pegawai, Penempatan seorang pegawai pada suatu jabatan yang tentunya memiliki beban kerja harus memperhatikan kompetensi yang dimiliki oleh seorang pegawai.Kompetensi tersebut dapat dilihat dari latar belakang pendidikannya, pengalaman, keahlian, bakat, dan keahlian managerialnya, dimana hal inilah yang kemudian mempengaruhi kinerjanya dalam menyelesaikan pekerjaan.Jadi sebisa mungkin pegawai ditempatkan sesuai dengan kompetensi yang dimilikinya.Walaupun hal tersebut belum bisa terpenuhi sepenuhnya, beban kerja yang ada sudah dianggap sesuai dengan kompetensi yang dimiliki oleh pegawai.

Kesesuaian beban kerja dengan Jumlah Pegawai, sudah sesuai karenayang namanya pekerjaan itu dibagi habis. Malahan tidak bagus kalau pegawai berlebih ada nanti yang tidak kerja.Kalau untuk Badan Kepegawaian Daerah semua bisa tertangani, karena kita punya uraian tugas masing-masing. Saya pikir jumlah pegawai yang ada sudah cukup dan untuk sementara ini tidak perlu ada penambahan pegawai lagi karna beban kerja dan jumlah pegawai pada BKD sudah cukup seimbang, secara keseluruhan sudah cukup. Kalau ada yang pensiun otomatiskan harus ada yang ganti. Kalau untuk sementara, kalau mau dilihat jumlah pegawai ini di BKD itu kelola semua persoalan administrasi kepegawaian, pegawai di pemerintah kota kan lahirnya kesini semua. Kalau untuk sekarang saya anggap cukuplah.Jadi dapat dikatakan bahwa Beban Kerja dan Jumlah Pegawai pada Badan Kepegawaian Daerah Kota Makassar sudah cukup seimbang, dan untuk sementara tidak perlu ada penambahan pegawai.

Untuk menentukan kebutuhan pegawai perlu juga diketahui besarnya waktu kerja yang digunakan oleh pegawai tersebut dalam menyelesaikan pekerjaan sehari-hari. 
Berkenaan dengan keefektifan dan keefisienan Standar Waktu Kerjaitu melihat suvisionalnya dan melihat tingkat skala prioritas jadi kalau pertama mengenai jam kerja, karena itu jam kerja adalah jam kerja yang disadari atau ditetapkan secara nasional, kalau kita melihat belum dianggap cukup efektif dan efisien untuk menyelesaikan pekerjaan. Untuk itu memperkuat pernyataan Waktu kerja dari pukul 07.30-15.30 dirasa sudah cukup efektif dan efisien untuk menyelesaikan pekerjaan. Sedangkan Standar waktu sudah normal karna Relatif setiap organisasi mempunyai kewenangan dan beban kerja tersendiri yang terkadang ada pekerjaan tersendiri yang membutuhkan waktu relatif yang singkat serta porsenil aparatur yang tidak terlalu banyak di butuhkan sehingga waktu yang ada dapat di gunakan dengan evisien namun ada kegiatan yang membutuhkan waktu cukup lama dan jumlah porsonil aparatur yang cukup banyak melebihi jumlah personalia yang ada dan kegiatan tersebut punya date lime sehingga waktu yang ada tidak efektif dan efisien lagi sesuai peraturan di Badan Kepegawaian Daerah Kota Makassar. Dengan demikian, standar waktu kerja yang telah ditetapkan secara nasional sudah cukup efektif dan efisien untuk menyelesaikan pekerjaan.

Syarat pendaftaran penerimaan calon pegawai negeri sipil yaitu: (a) Usia paling rendah 18 tahun dan paling tinggi 35 tahun pada saat pelamaran: (b) foto copy sah ijazah yang sesuai dengan kualifikasi pendidikan yang dibutuhkan (tanggal pengesahan maksimal 6 bulan pada saat pelamar; (c) Lulus perguruan tinggi yang terakreditas oleh BAN-PT; (d) Khusus jabatan penyuluh penanganan masalah social dengan kualifikasi pendidikan D.IV kesejahtraan Sosial dan jabatan penyuluh pelestarian nilai budaya dan tradisi dengan kualifikasi pendidikan S.1 Bahasa Daerah (PGSBD) wajib melampirkan SK. Walikota Makassar tentang penunjukan sebagai mahasiswa ikatan dinas; (e) Khusus jabatan Dokter Umum dan Dokter gigi wajib melampirkan surat keterangan selesai masa bakti dan bersedia ditempatkan di pulau; (f) Pas foto 3X4 sebanyak 3 lembar berlatar belakan merah; (g) Mendaftar melalui online di website mulai tanggal 23 agustus s/d 03 september 2014 melalui; (h) Untuk mengambil nomor tes bertempat di Badan Kepegawaian Daerah Kota Makassar J1. Jenderal Achmad 
Yani No. 2 Makassar dengan membawa nomor registrasi, foto copy ijazah yang dilegalisis dan pas foto $3 \mathrm{X} 4$ sebanyak 3 lembar berlatar belakang merah.

\section{KESIMPULAN}

Dari hasil penelitian berdasarkan wawancara serta observasi dan pembahasan yang telah dikemukakan pada bab sebelumnya tentang formasi kebutuhan pegawai Dalam penerimaan Calon Pegawai Negeri Sipil (CPN) Pada Badan Kepegawaian Daerah Kota Makassar berdasarkan Uraian Jabatan dan Formasi beban kerja, maka penulis dapat menarik kesimpulan bahwa Formasi Kebutuhan pegawai Dalam Penerimaan Calon Pegawai Negeri Sipil Pada Badan Kepegawaian Daerah Kota Makassar saat ini sudah terpenuhi, hal ini dapat dilihat dari berbagai wawancara yang dilakukan penulis dengan informan. Bahwa PNS hasil seleksi yang didapat setelah hasil formasi yang diajukan dan sesuai dengan potensi dan kualifikasi pendidikan yang di butuhkan SKPD Pemerintah secara umum.

Uraian pekerjaan pada Badan Kepegawaian Daerah Kota Makassar sudah jelas dan terperinci.Pegawai pada setiap bidang juga telah memahami dengan baik tugas-tugas yang diberikan.Selain itu, mereka telah memahami hubungan kerja antar bidang yang saling terkait, dan tetap memprioritaskan tugas dan tanggung jawab yang diterima dalam pekerjaan.

Jika dilihat dari latar belakang pendidikan, formasi pegawai pada BKD Kota Makassar belum seratus persen sesuai dengan latar belakang pendidikan.

\section{DAFTAR PUSTAKA}

Batinggi, dkk. (1998). Modul Manajemen Sumber Daya Manusia. Ujung Pandang: STIMIK Dipanegara.

Hasibuan, Malayu. (2011). Manajemen Sumber Daya Manusia. Jakarta: Bumi Aksara.

Manullang, M. (2000). Dasar-Dasar Manajemen.Yogyakarta: Gadjah Mada University Press. 89 
Nitisemito, Alex. (1982). Manajemen Personalia (Manajemen Sumber Daya Manusia). Jakarta: Ghalia Indoneisa.

Nanang Syaikhu. (2014). Kinerja Pegawai.http://www.uinjkt.ac.id. Diakses 27 April 2014.

Samsudin, Sadili. (2006). Manajemen Sumber Daya Manusia. Bandung: CV. Pustaka Setia.

Subekhi, Akhmad. (2012). Pengantar Manajemen Sumber Daya Manusia (MSDM). Jakarta: Prestasi Pustaka.

Sutrisno, Edy. (2009). Manajemen Sumber Daya Manusia. Jakarta: Kencana Prenada Media Group.

Teknik Analisis Data. (2011). http://edukasi.kompasiana.comDiakses25 April 2014.

Peraturan Perundang-undangan. (2014). http://www.google.com, Diakses 27April 2014.

Undang-Undang Nomor 5 Tahun 2014 tentang Aparatur Sipil Negara (ASN) Kepala Badan Kepegawaian Negara mengeluarkan surat Nomor K.2630/V.7-3/99. 